\title{
Resveratrol upregulates SIRT1 and inhibits cellular oxidative stress in the diabetic milieu: mechanistic insights
}

\author{
Jung-Mi Yun ${ }^{1}$, Alexander Chien ${ }^{1}$, Ishwarlal Jialal ${ }^{1}$, and Sridevi Devaraj ${ }^{1}$ \\ ${ }^{1}$ Department of Pathology and Laboratory Medicine, University of California, Davis, Medical \\ Center, Sacramento, USA
}

\section{Abstract}

Several lines of evidence support a role for oxidative stress in diabetic complications Diabetic patients have increased $\mathrm{O}_{2}^{-}$production in monocytes. Loss of SIRT1 activity may be associated with metabolic diseases such as diabetes. Several studies have shown that SIRT1 can regulate mammalian FOXO transcription factors through direct binding and/or deacetylation. However, interactions between SIRT1 and FOXO under diabetic conditions are unclear. The phytochemical resveratrol, has recently gained attention for its protection against metabolic disease. Resveratrol has been shown to increase mitochondrial function by activating SIRT1.

In this study, we tested the protective effect of resveratrol on cellular oxidative stress through the SIRT1-FOXO pathway under high-glucose conditions. Human monocytic (THP-1) cells were cultured in presence of mannitol (osmolar control) or normoglycemic (NG, $5.5 \mathrm{mmol} / \mathrm{L}$ glucose) or hyperglycemic (HG, $25 \mathrm{mmol} / \mathrm{L}$ glucose) conditions in absence or presence of resveratrol (3 and $6 \mu \mathrm{mol} / \mathrm{L}$ ) for $48 \mathrm{~h}$. We first examined SIRT1 activity and oxidative stress in monocytes of T1DM patients compared to healthy controls. In T1DM patients, monocytic SIRT1 expression was significantly decreased and $\mathrm{p} 47$ phox expression was increased compared to controls. Under HG in vitro, SIRT1 and FOXO3a were significantly decreased compared to NG, this was reversed by resveratrol treatment, concomitant with reduction in HG-induced superoxide production and p47phox. Under HG, SIRT1 small interfering RNA (siRNA), inhibited FOXO3a and there was no beneficial effect of resveratrol in siRNA treated HG-induced cells. Thus, resveratrol decreases HG-induced superoxide production via upregulation of SIRT1, induction of FOXO3a and inhibition of p47phox in monocytes.

\section{Keywords}

SIRT1; FOXO3a; p47phox; oxidative stress; resveratrol and diabetes

\section{Introduction}

Hyperglycemia contributes to vascular complications of diabetes. High glucose has been shown to induce inflammatory cytokines, chemokines, p38 mitogen-activated protein

\footnotetext{
(C) 2011 Elsevier Inc. All rights reserved.

*Correspondence to: Sridevi Devaraj PhD, DABCC, FACB, CCRP, Professor, Department of Pathology, Research Bldg 1, Rm 3000, Laboratory for Atherosclerosis and Metabolic Research, UC Davis Medical Center, 4635, Second Ave, Sacramento CA 95817, Tel:9167346594, Fax:9167346593, Pager:9167624910, sridevi.devaraj@ucdmc.ucdavis.edu.

Publisher's Disclaimer: This is a PDF file of an unedited manuscript that has been accepted for publication. As a service to our customers we are providing this early version of the manuscript. The manuscript will undergo copyediting, typesetting, and review of the resulting proof before it is published in its final citable form. Please note that during the production process errors may be discovered which could affect the content, and all legal disclaimers that apply to the journal pertain.
} 
kinase, reactive oxygen species (ROS), protein kinase C (PKC), and nuclear factor- $\mathrm{kB}$ (NF$\kappa B)$ activity in both clinical and experimental systems (1-6). Several lines of evidence support a role for oxidative stress in the development of diabetes complications (7-8). Diabetic patients have increased $\mathrm{O}_{2}{ }^{-}$production in monocytes and neutrophils $(2,7,9)$. Excess accumulation of ROS can result from defects in ROS scavenging and is believed to have an impact on cellular aging and the senescence process (10). NADPH oxidase is accepted as the most important mechanism for ROS generation in phagocytic cells. Previously, we have shown that p47phox, an essential component of monocyte NADPH oxidase, is required for ROS generation under high glucose conditions (11).

Recently, SIRT1, the mammalian homologue of yeast Sir2, was identified as a key mediator that links calorie restriction and longevity in mammals. Sirtuins are a conserved family of NAD-dependent deacetylases (class III histone deacetylases) (12-16). To date, seven members of sirtuin proteins (i.e., SIRT1-SIRT7) have been identified in humans. Recent studies have demonstrated that SIRT1 plays an important role in the regulation of cell death/ survival and stress response in mammals. SIRT1 promotes cell survival by inhibiting apoptosis or cellular senescence induced by stresses, including DNA damage and oxidative stress (12-17). An increasing number of proteins have been identified as substrates of SIRT1, including p53 (18-21), Forkhead box O (FOXO) transcription factors (22-28). Improper regulation of sirtuin proteins has been reported in a number of diseases, including Bowen's disease (29), type I diabetic nephropathy (30), Alzheimer disease and amyotrophic lateral sclerosis (31), and non alcoholic fatty liver disease (32). It has been suggested that loss of Sirt1 activity may be associated with metabolic diseases such as type 2 diabetes and atherosclerosis (33-35).

FOXO transcription factors FOXO1 (FKHR) (36), FOXO3a (FKHRL1) (37), FOXO4 (ARX) (38), and FOXO6 (39), are emerging as an important family of proteins that modulate the expression of genes involved in apoptosis, the cell cycle, DNA damage repair, oxidative stress, cell differentiation, glucose metabolism and other cellular functions (22-24, 26, 40). Several studies have shown that SIRT1 can control the cellular response stress by regulate mammalian FOXO transcription factors through direct binding and/or deacetylation $(12,22,24,26,28,41)$. However, the mechanism of the interactions between SIRT1 and FOXO under hyperglycemic conditions is not well understood. FOXO transcription factors regulate antioxidant expression and DNA damage repair. Among all FOXO members, FOXO3a appears to have an important role under oxidative stress. Foxo3 plays an important role in the in vivo regulation of oxidative stress in mammals. FOXO3a upregulates transcription of the ROS scavenging enzymes superoxide dismutase 2 (SOD2, also known as MnSOD) and catalase (42-44). Thus, FOXO3 appears to be a critical physiological regulator of oxidative stress in mammalian cells.

One important sirtuin-activating compounds is the natural product resveratrol $(3,4,5$ trihydroxystilbene), a polyphenol that is synthesized by plants and is present in grapes and red wine (45). Recently, resveratrol has been shown to improve energy balance and increase mitochondrial function in mice by activating SIRT1 (46). Resveratrol has previously gained considerable attention because of its beneficial effects as a cardioprotective, cancer chemopreventive, and chemotherapeutic agent (47-51)

Previously, we have shown increased monocytic superoxide in T2DM and T1DM and subsequently showed under $\mathrm{HG}$ condition that this is mediated via upregulation of $\mathrm{PKCa}$ and p47phox (11). However, the role of SIRT1 in regulating monocytic superoxide under HG condition is not well understood. Moreover, the effect of resveratrol, a potent SIRT1 inducer, on monocyte superoxide under HG conditions is not elucidated and is the focus of the present report. Thus, we hypothesize that resveratrol, can suppress ROS production via 
regulatory mechanism involving FOXO3a, SIRT1 and p47phox under high glucose conditions in human monocytes.

\section{Materials and Methods}

\section{Materials}

Anti-FoxO family antibodies were procured from cell signaling technology(Danvers, MA, USA) and anti-SIRT1 was procured from Abcam (Cambridge, MA, USA). Dihydroethidium was purchased from Molecular Probes (Eugene, OR, USA). HDAC assay reagents (colorimetric) were purchased from Biovision (Mountain View, CA, USA). The BCA ${ }^{\mathrm{TM}}$ protein assay kit was purchased from Pierce. Novex pre-cast Tris-Glycine gels were obtained from Invitrogen (Carlsbad, CA). All other chemicals, unless otherwise stated, were obtained from Sigma (St. Louis, MO).

\section{Cell culture and Treatment with resveratrol}

Human monocytes were obtained from T1DM patients and healthy controls as detailed previously (52). Human monocytic THP-1 cell line was obtained from American Type Culture Collection (Manassas, VA). THP-1 cells were cultured in RPMI medium containing $10 \%$ fetal bovine serum and $1 \%$ antibiotics at $37{ }^{\circ} \mathrm{C}$ and $5 \% \mathrm{CO}_{2}$. resveratrol (dissolved in DMSO) was used for the treatment of cells. The final concentration of DMSO used was $0.1 \%(\mathrm{v} / \mathrm{v})$ for each treatment. Human monocytic $(\mathrm{THP}-1)$ cells $\left(1 \times 10^{5} \mathrm{cells} / \mathrm{ml}\right)$ were cultured in presence of osmolar control (19.5 mmol/L mannitol) or normoglycemic (NG, 5.5 $\mathrm{mmol} / \mathrm{L}$ glucose) or hyperglycemic (HG, $25 \mathrm{mmol} / \mathrm{L}$ ) conditions in absence or presence of resveratrol $(3,6 \mu \mathrm{mol} / \mathrm{L})$ for $48 \mathrm{~h}$. Cells were washed with phosphate-buffered saline (PBS) and then harvested.

\section{Trypan Blue Exclusion Assay}

Following treatments, cells were trypsinized and collected in a $1.5-\mathrm{ml}$ eppendorf tube. The cells were pelleted by centrifugation and resuspended in PBS $(120 \mu \mathrm{l})$. Trypan blue $(0.4 \%$ in PBS; $10 \mu \mathrm{l})$ was added to a smaller aliquot $(10 \mu \mathrm{l})$ of cell suspension, and the number of cells (viable unstained and nonviable blue) were counted.

\section{Immunostaining}

For detection of SIRT1 by immunofluorescence, after treatment of cells with resveratrol, the cells were centrifuged and medium was aspirated. Cells were washed twice in PBS (10 $\mathrm{mmol} / \mathrm{L}, \mathrm{pH}$ 7.4) and placed on L-lysine coasted slides, the slides were air dried, fixed with $4 \%$ formaldehyde for $30 \mathrm{~min}$ at $4^{\circ} \mathrm{C}$ and stained overnight at $4^{\circ} \mathrm{C}$ with SIRT1 and FOXO3a antibodies (1:1000 dilution). After being air dried, slides were incubated with appropriate secondary antibody for $60 \mathrm{~min}$. The slides were washed as described above, air dried, mounted with mounting medium, and then examined with a fluorescence microscope at 400 $\times$ magnification. In order to measure immunostaining intensity of Foxo3a and Sirt1, images were captured with a Nikon eclipse TE200 camera (Japan). The signal intensity was measured using ImageJ software.

\section{Preparation of Nuclear fraction}

After treatment of cells with resveratrol the medium was aspirated and the cells washed twice in PBS (10 mmol/L, pH 7.4). Nuclear lysates were prepared using NE-PER Nuclear and Cytoplasmic Extraction Reagents (Pierce). Nuclear lysates were collected and cleared by centrifugation, and the supernatant aliquoted and stored at $-80^{\circ} \mathrm{C}$. The protein content in the lysates was measured by BCA protein assay (Pierce), as per the manufacturer's protocol. 


\section{Measurement of HDAC activity using ELISA}

Following treatment of cells with various concentrations of resveratrol for $48 \mathrm{~h}$, cells were harvested and nuclear lysates were prepared. $10 \mu \mathrm{g}$ of nuclear lysate protein from each group were taken for determination of HDACs activity, respectively. The experiment was done according to the manufacturer's instructions. Absorbancewas taken at $405 \mathrm{~nm}$ and $440 \mathrm{~nm}$.

\section{Western Blot Analysis}

For Western blot analysis, $12 \mu \mathrm{g}$ of protein resolved over $10 \%$ Tris-glycine polyacrylamide gels (Novex), transferred onto nitrocellulose membranes, and subsequently incubated in blocking buffer [5\% nonfat dry milk/1\% Tween 20; in $20 \mathrm{mmol} / \mathrm{L}$ TBS (pH 7.6)] for $2 \mathrm{~h}$. The blots were incubated with appropriate primary antibody (SIRT1, FOXO1a, FOXO3a and $\mathrm{p} 47 \mathrm{phox}$ ) washed, and incubated with appropriate secondary horseradish peroxidaseconjugated antibody (Amersham Biosciences). The blots were detected with chemiluminescence (ECL kit, Amersham Biosciences) and autoradiography, using XAR-5 film (Eastman Kodak). Equal loading of protein was confirmed by stripping the blots and reprobing with Lamin (Sigma)

\section{Measurement of intracellular superoxide production}

To assess the production of superoxide, NG, HG and HG-resveratrol treated cells were incubated with $5 \mu \mathrm{mol} / \mathrm{L}$ dihydroethidium (DHE; Molecular Probes, Eugene, OR), which is oxidized to the fluorescent intercalator, ethidium by cellular oxidants, particularly superoxide radicals. Cells $\left(1 \times 10^{5}\right)$ were stained with $5 \mu \mathrm{mol} / \mathrm{L}$ dihydroethidium for 30 minutes at $37^{\circ} \mathrm{C}$ and were washed and resuspended in PBS. The oxidative conversion of dehydroxyethidium to ethidium was measured by flow cytometry.

\section{SiRNA transfection assays}

Prevalidated siRNAs were obtained from Santa Cruz biotech., and transfection assays were performed as described previously (53-54) following the manufacturer's instructions, with suitable vehicle and scrambled siRNA controls. Transfection efficiency was around $70 \%$. Subsequently, Human monocytic cells $\left(1 \times 10^{5}\right.$ cells $\left./ \mathrm{ml}\right)$ were cultured in presence of osmolar control ( $9.5 \mathrm{mmol} / \mathrm{L}$ mannitol) or euglycemic (EG, $5.5 \mathrm{mmol} / \mathrm{L}$ glucose) or hyperglycemic ( $\mathrm{HG}, 25 \mathrm{mmol} / \mathrm{L})$ conditions in absence or presence of resveratrol $(3,6 \mu \mathrm{mol} /$ L) for $48 \mathrm{~h}$. Then, cells were washed with phosphate-buffered saline (PBS) and harvested.

\section{Statistical analysis}

Each experiment was performed at least three times. Results are expressed as the means value \pm standard deviation (SD). Statistical analysis was performed using Student's $t$-test and statistical significance is expressed as ${ }^{*}, P<0.05,{ }^{* *}, P<0.01$.

\section{Results}

\section{SIRT1 expression and $\mathrm{O}_{2}^{-}$production are altered in T1DM patients compared to normal healthy controls}

We first examined SIRT1 expression in monocytes of T1DM patients compared to normal healthy controls (Fig. 1). In T1DM patients, SIRT1 expression was significantly decreased compared to healthy controls ( $\mathrm{n}=8$ /group). Monocyte membrane $\mathrm{p} 47$ phox expression was significantly increased in T1DM compared to healthy controls $(\mathrm{p}<0.001)$. In addition, as shown previously (11), T1DM monocytes released significantly increased $\mathrm{O}_{2}{ }^{-}$as evidenced by increased DHE staining. 


\section{In vitro treatment with resveratrol significantly induced SIRT1 expression in HG conditions}

In order to examine mechanisms we tested pathways in human monocytic cells under HG conditions. Furthermore since resveratrol upregulates SIRT1 we tested the effect of resveratrol on $\mathrm{O}_{2}{ }^{-}$production in monocytes under $\mathrm{HG}$ conditions. Next, we examined the effect of HG compared to NG on SIRT1 expression level by immunoblotting (Fig. 2A). Under HG, SIRT1 was significantly decreased compared to NG. Also, as shown in Fig. 2B, HDACs activity was decreased in HG conditions and this decrease was reversed by resveratrol $(3$ and $6 \mu \mathrm{mol} / \mathrm{L})$ treatment.

\section{In vitro treatment with resveratrol significantly induced FOXO3a expression in HG conditions}

Next, we studied its specific regulation mechanisms. SIRT1 expression is associated with activation of FOXO family proteins. Under HG, FOXO3a expression was significantly decreased compared to NG $(\mathrm{p}<0.001)$. As shown in Fig. $2 \mathrm{C}$, downregulation of FOXO3a under high glucose-induced conditions was significantly reversed by resveratrol ( 3 and 6 $\mu \mathrm{mol} / \mathrm{L}$ ) treatment. These findings were confirmed by immunofluorescene analysis (Fig. 3A and B). However, there was no effect on FOXO1a or p53 (data not shown.

\section{In vitro treatment with resveratrol significantly suppressed $\mathrm{O}_{2}^{-}$production in $\mathrm{HG}$ conditions}

We examined the production of superoxide using dihydroethidium. Under HG, superoxide production were significantly increased compared to NG ( $\mathrm{p}<0.001$ ). As shown in Figure 4A, increased superoxide production under high glucose-induced monocytes was significantly downregulated by resveratrol $(3$ and $6 \mu \mathrm{M})$ treatment. p47 phox is an essential component of monocyte NADPH oxidase production and required for ROS generation under high glucose conditions (11). Therefore, we examined effect of resveratrol on NADPH oxidase (p47 phox) under high glucose. Under HG, p47 phox expression in the cell membrane were significantly increased compared to NG ( $\mathrm{p}<0.001)$. As shown in Figure 4B, upregulated p47phox expression in high glucose-induced monocytes was significantly downregulated by resveratrol ( 3 and $6 \mu \mathrm{mol} / \mathrm{L})$ treatment.

\section{With SIRT1 knockdown, resveratrol fails to affect intracellular superoxide production}

To determine if SIRT1 modulates FOXO3a and p47phox specifically in HG conditions in monocytes resulting in decreased superoxide, we employed an additional approach of RNA interference-mediated knockdown of the SIRT1 gene. As shown in Fig. 5A-B, SIRT1 small interfering RNA inhibited FOXO3a but not p47phox expression in HG- induced monocytic cells. Furthermore, in presence of resveratrol, there was no effect in SIRT1 siRNA -treated cells, showing that resveratrol primarily acts via SIRT1. In these cells, under HG conditions, resveratrol did not affect FOXO1A or p53 expression (data not shown).

\section{Discussion}

Diabetic patients have increased $\mathrm{O}_{2}^{-}$production in monocytes and neutrophils $(2,7,9)$. Hyperglycemia-induced production of ROS is a key event in the development of diabetic complications $(2,7,8,10)$. Dandona et al (55) elucidated the role of ROS in diabetes by showing also increased oxidative DNA damage in diabetics compared to controls. Previously, we have shown that p47phox is an essential component of monocyte NADPH oxidase production and required for ROS generation under high glucose conditions in vitro (11) and Mohanty et al have observed increased p47phox in humans in vivo (56). So far, the exact mechanism in diabetes is not known at present. Recently, Sirtuins have been implicated in metabolic processes and stress resistance. Recent studies have been suggested 
a key role for the mammalian SIRT1 in the adequate cellular response to metabolic stress events such as nutrient overload or nutrient deprivation (57). In fact, the effects of SIRTs appear to be beneficial. SIRT1-knockout and overexpressor mouse models have demonstrated metabolic benefits of Sirt1 activation. Recently, it has been proposed that SIRT1 is an important regulator of many factors influencing obesity and type 2 diabetes (58) and also a possible target for the treatment of Metabolic syndrome (59-60).

SIRT1, belongs to class III histone/protein deacetylases (HDACs), the most extensively studied of the sirtuins. SIRT1, through its deacetylase activity, is regarded as a key regulator of cell defense and survival under various stress conditions by deacetylating the p53 (18-21) and forkhead transcription factor $(14,22,37)$. The effect of SIRT1 might be linked on FOXO function. Several studies have shown that SIRT1 can regulate mammalian FOXO transcription factors through direct binding and/or deacetylation. However, the mechanism of the interactions between SIRT1 and FOXO under diabetic conditions is not well understood. As one possible mechanism, SIRT1 enhances the activity of the FOXO by their nuclear translocation (22) and probably regulates the gene-specific transcription $(24,35,42$, 44). The translocation of FOXO3a from the cytoplasm to the nucleus is induced by deacetylation by SIRT1 in response to oxidative stress $(22,61)$. Among FOXO family, FOXO3a (also known as FKHR-L1) have been known that it protects quiescent cells from oxidative stress by directly increasing their quantities of manganese superoxide dismutase (MnSOD) messenger RNA and protein (44). Recently, Barthel et al have suggested that the FOXO3a genotype was significantly associated with plasma insulin levels as well as CHD, cancer, and Type 2 diabetes prevalence. The results of recent reports reveal that FOXO3a is an important regulator influencing obesity and diabetes. As an important downstream mechanism, FOXO3a might, at least in part, influence human metabolic diseases through modification of oxidative stress (62-63).

Resveratrol is a polyphenol existing in grapes, berries, and peanuts. It has been reported to activate SIRT1 and extends life span in multiple model organisms (60). In addition, It has been suggested that resveratrol is a promising new therapeutic approach for preventing cardiovascular diseases in type 2 diabetes and aging $(47,63)$. In addition, resveratrol has been reported to confer vasoprotection, improving endothelial function and preventing complications of diabetes in animal models (46, 48-51, 65-67).

Diabetes and aging are characterized by increased cellular ROS production, yet the effects of resveratrol on oxidative stress in human monocytes remain incompletely understood. Recently, there is evidence to suggest that resveratrol suppresses ROS generation via inhibiting NADPH oxidase activity (68). Resveratrol suppresses ROS generation via FOXO3a (69) and upregulates MnSOD expression via SIRT1 activation (70). Recently Orimo et al (71) have suggested that hyperglycemia decreases SIRT1 expression and activation of SIRT1 prevents the hyperglycemia-induced endothelial senescence and thereby protects against vascular dysfunction in mice with diabetes (71). As a mechanism, they have been suggested that the Akt/FOXO pathway plays a crucial role in the downregulation of SIRT1 expression by high-glucose conditions (71). Previous studies have demonstrated that high glucose reduced SIRT1 expression leading to increased p53 and FOXO3a acetylation (57). Also, very recently, Viglili de Kreutzenbarg et al have shown that insulin resistance and metabolic syndrome affects SIRT1 gene (72). Despite these previous reports, correlation with FOXO3a, SIRT1 and monocyte p47phox on ROS generation under HG conditions has not been not studied and its mechanism is still unclear.

Based on a previous study, we suggest that SIRT1 could serve as a target toward developing novel strategies for diabetes. We focused on its regulatory mechanism involving FOXO3a, SIRT1 and p47phox under HG-mediated oxidative stress of human monocytes. We 
investigated the effect of resveratrol on ROS production via SIRT1-FOXO3a signaling in HG-induced monocytes. Thus, we determined whether resveratrol, can be used as a therapeutic agent for diabetic complications.

In the present study, first of all, we observed decreased SIRT1 and increased p47phox expression in monocytes of T1DM patients compared to normal healthy controls. The results of the present study, exposure of human monocytes to a high concentration of glucose led to a decrease in nuclear SIRT1 and FOXO3a and a parallel increase in membrane p47phox expression and superoxide production. Interestingly, in this study, there was no change in FOXO1a expression or p53 by HG-induced oxidative and moreover there was no change by resveratrol.

When we employed an additional approach of RNA interference-mediated knockdown of the SIRT1 gene, we observed that SIRT1 siRNA inhibited FOXO3a in HG-induced monocytes. Resveratrol failed to inhibit intracellular superoxide when SIRT 1 is knocked down, these results indicate that resveratrol primarily acts by inducing SIRT1, inducing FOXO3a and decreasing $\mathrm{p} 47$ phox resulting in decreased superoxide production under HG conditions in monocytes.

Thus, in our study, we show that HG suppresses SIRT1-FOXO3a pathway leading to increased $\mathrm{p} 47$ phox expression and monocytic ROS production. Resveratrol treatment of HG-induced cells activates HDACs and induces SIRT1 and FOXO3a expression, subsequently suppressing production of ROS and p47phox activation in monocytes (Fig 6). Ghanim et al (73) previously showed that a polygonium extract containing resveratrol significantly reduced in reactive oxygen species generation, the expression of $\mathrm{p} 47^{\text {phox }}$, intranuclear nuclear factor- $\mathrm{kB}$ binding, in mononuclear cells of healthy subjects when compared with the baseline and the placebo, but had no effect on SIRT1. Furthermore, resveratrol resulted in decreased PTP-1B, SOCS-3, JNK-1 and IKK-beta, and it has been shown that these proteins interfere with insulin signal transduction However, this study was not under hyperglycemia and the extract contained only $20 \%$ resveratrol, thus other products may have also contributed to these findings. Our study indicates that activation of FOXO3a pathway is a key protective pathway against oxidative stress in high glucose conditions. However, resveratrol will need extensive evaluation in clinical trials before it can be recommended for retarding oxidative stress and diabetic complications.

\section{Acknowledgments}

J.Y, S.D and I.J designed the studies and wrote the manuscript. All the authors read and approved the final manuscript. We also thank Manpreet Kaur for editorial assistance

Supported by grants from the NIH, K24 AT00596 (IJ) and R33 DK69801 (SD)

\section{Literature Cited}

1. Jialal I, Devaraj S, Venugopal SK. Oxidative stress, inflammation, and diabetic vasculopathies: the role of alpha tocopherol therapy. Free Radic Res. 2002; 6:1331-1336. [PubMed: 12607825]

2. Jain SK, Kannan K, Lim G, Matthew-Greer J, McVie R, Bocchini JA. Elevated blood interleukin-6 levels in hyperketonemic type 1 diabetic patients and secretion by acetoacetate-treated cultured U937 monocytes. Diabetes Care. 2003; 26:2139-2143. [PubMed: 12832326]

3. Shanmugam N, Reddy MA, Guha M, Natarajan R. High-glucose-induced expression of proinflammatory cytokine and chemokine genes in monocytic cells. Diabetes. 2003; 52:1256-1264. [PubMed: 12716761] 
4. Igarashi M, Wakasaki H, Takahara N, Ishii H, Jiang ZY, Yamauchi T, Kuboki K, Meier M, Rhodes CJ, King GL. Glucose or diabetes activates p38 mitogen-activated protein kinase via different pathways. J Clin Invest. 1999; 103:185-195. [PubMed: 9916130]

5. Ceolotto G, Gallo A, Miola M, Sartori M, Trevisan R, Prato SD, Semplicini A, Avogaro A. Protein kinase $\mathrm{C}$ activity is acutely regulated by plasma glucose concentration in human monocytes in vivo. Diabetes. 1999; 48:1316-1322. [PubMed: 10342822]

6. Dandona P, Chaudhuri A, Ghanim H, Mohanty P. Proinflammatory effects of glucose and antiinflammatory effect of insulin: relevance to cardiovascular disease. Am J Cardiol. 2007; 99:15B$26 \mathrm{~B}$.

7. Hill H, Hogan N, Rallison M, Santos JI, Charette RP, Kitahara M. Functional and metabolic abnormalities of diabetic monocytes. Adv Exp Med Biol. 1980; 69:621-627.

8. Yan SF, Ramasamy R, Schmidt AM. Mechanisms of disease: advanced glycation end-products and their receptor in inflammation and diabetes complications. Nat Clin Pract Endocrinol Metab. 2008; 4:285-293. [PubMed: 18332897]

9. Devaraj S, Venugopal SK, Singh U, Jialal I. Hyperglycemia induces monocytic release of interleukin-6 via induction of protein kinase C-alpha and beta. Diabetes. 2005; 54:85-91. [PubMed: 15616014]

10. Beckman KB, Ames BN. The free radical theory of aging matures. Physiol Rev. 1998; 78:547581. [PubMed: 9562038]

11. Venugopal SK, Devaraj S, Yang T, Jialal I. a -Tocopherol Decreases Superoxide Anion Release in Human Monocytes Under Hyperglycemic Conditions Via Inhibition of Protein Kinase C-a. Diabetes. 2002; 51(10):3049-3054. [PubMed: 12351446]

12. Longo VD, Kennedy BK. Sirtuins in aging and age-related disease. Cell. 2006; 126:257-268. [PubMed: 16873059]

13. Marmorstein R. Structure and chemistry of the Sir2 family of NAD+-dependent histone/protein deactylases. Biochem Soc Trans. 2004; 32:904-909. [PubMed: 15506920]

14. Michan S, Sinclair D. Sirtuins in mammals: insights into their biological function. Biochem J. 2007; 404:1-13. [PubMed: 17447894]

15. Sauve AA, Wolberger C, Schramm VL, Boeke JD. The biochemistry of sirtuins. Annu Rev Biochem. 2006; 75:435-465. [PubMed: 16756498]

16. Haigis MC, Guarente LP. Mammalian sirtuins--emerging roles in physiology, aging, and calorie restriction. Genes Dev. 2006; 20:2913-2921. [PubMed: 17079682]

17. Ying W. NAD+ and NADH in cellular functions and cell death. Front Biosci. 2006; 11:31293148. [PubMed: 16720381]

18. Cheng HL, Mostoslavsky R, Saito S, Manis JP, Gu Y, Patel P, Bronson R, Appella E, Alt FW, Chua KF. Developmental defects and p53 hyperacetylation in Sir2 homolog (SIRT1)-deficient mice. Proc Natl Acad Sci USA. 2003; 100:10794-10799. [PubMed: 12960381]

19. Langley E, Pearson M, Faretta M, Bauer UM, Frye RA, Minucci S, Pelicci PG, Kouzarides T. Human SIR2 deacetylates p53 and antagonizes PML/p53-induced cellular senescence. EMBO J. 2002; 21:2383-2396. [PubMed: 12006491]

20. Luo J, Nikolaev AY, Imai S, Chen D, Su F, Shiloh A, Guarente L, Gu W. Negative control of p53 by Sir2alpha promotes cell survival under stress. Cell. 2001; 19:137-148. [PubMed: 11672522]

21. Vaziri H, Dessain SK, Ng EE, Imai SI, Frye RA, Pandita TK, Guarente L, Weinberg RA. hSIR2(SIRT1) functions as an NAD-dependent p53 deacetylase. Cell. 2001; 19:149-159. [PubMed: 11672523]

22. Brunet A, Sweeney LB, Sturgill JF, Chua KF, Greer PL, Lin Y, Tran H, Ross SE, Mostoslavsky R, Cohen HY, Hu LS, Cheng HL, Jedrychowski MP, Gygi SP, Sinclair DA, Alt FW, Greenberg ME. Stress-dependent regulation of FOXO transcription factors by the SIRT1 deacetylase. Science. 2004; 303:2011-2015. [PubMed: 14976264]

23. Frescas D, Valenti L, Accili D. Nuclear trapping of the forkhead transcription factor FoxO1 via Sirt-dependent deacetylation promotes expression of glucogenetic genes. J Biol Chem. 2005; 280:20589-20595. [PubMed: 15788402] 
24. Kobayashi Y, Furukawa-Hibi Y, Chen C, Horio Y, Isobe K, Ikeda K, Motoyama N. SIRT1 is critical regulator of FOXO-mediated transcription in response to oxidative stress. Int J Mol Med. 2005; 16:237-243. [PubMed: 16012755]

25. Li H, Liu JP. Signaling on telomerase: a master switch in cell aging and immortalization. Biogerontology. 2002; 3:107-116. [PubMed: 12014828]

26. Yang Y, Hou H, Haller EM, Nicosia SV, Bai W. Suppression of FOXO1 activity by FHL2 through SIRT1-mediated deacetylation. EMBO J. 2005; 24:1021-1032. [PubMed: 15692560]

27. Balestrieri ML, Rienzo M, Felice F, Rossiello R, Grimaldi V, Milone L, Casamassimi A, Servillo L, Farzati B, Giovane A, Napoli C. High glucose downregulates endothelial progenitor cell number via SIRT1. Biochim Biophys Acta. 2008; 1784:936-945. [PubMed: 18423418]

28. Motta MC, Divecha N, Lemieux M, Kamel C, Chen D, Gu W, Bultsma Y, McBurney M, Guarente L. Mammalian SIRT1 represses forkhead transcription factors. Cell. 2004; 116:551-563. [PubMed: 14980222]

29. Hida Y, Kubo Y, Murao K, Arase S. Strong expression of a longevity-related protein, SIRT1, in Bowen's disease. Arch Dermatol Res. 2007; 299:103-106. [PubMed: 17180656]

30. Tikoo K, Tripathi DN, Kabra DG, Sharma V, Gaikwad AB. Intermittent fasting prevents the progression of type I diabetic nephropathy in rats and changes the expression of Sir2 and p53. FEBS Lett. 2007; 581:1071-1078. [PubMed: 17316625]

31. Kim D, Nguyen MD, Dobbin MM, Fischer A, Sananbenesi F, Rodgers JT, Delalle I, Baur JA, Sui G, Armour SM, Puigserver P, Sinclair DA, Tsai LH. SIRT1 deacetylase protects against neurodegeneration in models for Alzheimer's disease and amyotrophic lateral sclerosis. EMBO J. 2007; 26:3169-3179. [PubMed: 17581637]

32. Deng XQ, Chen LL, Li NX. The expression of SIRT1 in nonalcoholic fatty liver disease induced by high-fat diet in rats. Liver Int. 2007; 27:708-715. [PubMed: 17498258]

33. de Kreutzenberg SV, Ceolotto G, Papparella I, Bortoluzzi A, Semplicini A, Dalla Man C, Cobelli C, Fadini GP, Avogaro A. Downregulation of the longevity-associated protein sirtuin 1 in insulin resistance and metabolic syndrome: potential biochemical mechanisms. Diabetes. 2010; 59(4): 1006-1015. [PubMed: 20068143]

34. Ota H, Eto M, Ogawa S, Iijima K, Akishita M, Ouchi Y. SIRT1/eNOS Axis as a Potential Target against Vascular Senescence, Dysfunction and Atherosclerosis. Atheroscler Thromb. 2010 [Epub ahead of print].

35. Milne JC, Lambert PD, Schenk S, Carney DP, Smith JJ, Gagne DJ, Jin L, Boss O, Perni RB, Vu CB, Bemis JE, Xie R, Disch JS, Ng PY, Nunes JJ, Lynch AV, Yang H, Galonek H, Israelian K, Choy W, Iffland A, Lavu S, Medvedik O, Sinclair DA, Olefsky JM, Jirousek MR, Elliott PJ, Westphal CH. Small molecule activators of SIRT1 as therapeutics for the treatment of type 2 diabetes. Nature. 2007; 450(7170):712-716. [PubMed: 18046409]

36. Galili N, Davis RJ, Fredericks WJ, Mukhopadhyay S, Rauscher FJ 3rd, Emanuel BS, Rovera G, Barr FG. Fusion of a fork head domain gene to PAX3 in the solid tumour alveolar rhabdomyosarcoma. Nat Genet. 1993; 5:230-235. [PubMed: 8275086]

37. Anderson MJ, Viars CS, Czekay S, Cavenee WK, Arden KC. Cloning and characterization of three human forkhead genes that comprise an FKHR-like gene subfamily. Genomics. 1998; 47:187-199. [PubMed: 9479491]

38. Parry P, Wei Y, Evans G. Cloning and characterization of the $t(X ; 11)$ breakpoint from a leukemic cell line identify a new member of the forkhead gene family. Genes Chromosomes Cancer. 1994; 11:79-84. [PubMed: 7529552]

39. Jacobs FM, van der Heide LP, Wijchers PJ, Burbach JP, Hoekman MF, Smidt MP. FoxO6, a novel member of the FoxO class of transcription factors with distinct shuttling dynamics. J Biol Chem. 2003; 278:35959-35967. [PubMed: 12857750]

40. Brunet A, Bonni A, Zigmond MJ, Lin MZ, Juo P, Hu LS, Anderson MJ, Arden KC, Blenis J, Greenberg ME. Akt promotes cell survival by phosphorylating and inhibiting a Forkhead transcription factor. Cell. 1999; 96:857-868. [PubMed: 10102273]

41. Giannakou ME, Partridge L. The interaction between FOXO and SIRT1: tipping the balance towards survival. Trends Cell Biol. 2004; 14:408-412. [PubMed: 15308206] 
42. Nemoto S, Finkel T. Redox regulation of forkhead proteins through a p66shc-dependent signaling pathway. Science. 2002; 295:2450-2452. [PubMed: 11884717]

43. Dijkers PF. Forkhead transcription factor FKHR-L1 modulates cytokine-dependent transcriptional regulation of p27(KIP1). Mol Cell Biol. 2000; 20:9138-9148. [PubMed: 11094066]

44. Kops GJ, Dansen TB, Polderman PE, Saarloos I, Wirtz KW, Coffer PJ, Huang TT, Bos JL, Medema RH, Burgering BM. Forkhead transcription factor FOXO3a protects quiescent cells from oxidative stress. Nature. 2002; 419:316-321. [PubMed: 12239572]

45. Pervaiz S. Resveratrol: from grapevines to mammalian biology. FASEB J. 2003; 17(14):19751985. [PubMed: 14597667]

46. Baur JA, Pearson KJ, Price NL, Jamieson HA, Lerin C, Kalra A, Prabhu VV, Allard JS, LopezLluch G, Lewis K, Pistell PJ, Poosala S, Becker KG, Boss O, Gwinn D, Wang M, Ramaswamy S, Fishbein KW, Spencer RG, Lakatta EG, Le Couteur D, Shaw RJ, Navas P, Puigserver P, Ingram DK, de Cabo R, Sinclair DA. Resveratrol improves health and survival of mice on a high-calorie diet. Nature. 2006; 444:337-342. [PubMed: 17086191]

47. Baur JA, Sinclair DA. Therapeutic potential of resveratrol: the in vivo evidence. Nat Rev Drug Discov. 2006; 5:493-506. [PubMed: 16732220]

48. Sharma S, Anjaneyulu M, Kulkarni SK, Chopra K. Resveratrol, a polyphenolic phytoalexin, attenuates diabetic nephropathy in rats. Pharmacology. 2006; 76:69-75. [PubMed: 16286809]

49. Su HC, Hung LM, Chen JK. Resveratrol, a red wine antioxidant, possesses an insulin-like effect in streptozotocin-induced diabetic rats. Am J Physiol Endocrinol Metab. 2006; 290:E1339-E1346. [PubMed: 16434553]

50. Thirunavukkarasu M, Penumathsa SV, Koneru S, Juhasz B, Zhan L, Otani H, Bagchi D, Das DK, Maulik N. Resveratrol alleviates cardiac dysfunction in streptozotocin-induced diabetes: role of nitric oxide, thioredoxin, and heme oxygenase. Free Radic Biol Med. 2007; 43:720-729. [PubMed: 17664136]

51. Zang M, Xu S, Maitland-Toolan KA, Zuccollo A, Hou X, Jiang B, Wierzbicki M, Verbeuren TJ, Cohen RA. Polyphenols stimulate AMP-activated protein kinase, lower lipids, and inhibit accelerated atherosclerosis in diabetic LDL receptor-deficient mice. Diabetes. 2006; 55:21802191. [PubMed: 16873680]

52. Devaraj S, Dasu MR, Rockwood J, Winter W, Griffen SC, Jialal I. Increased toll-like receptor (TLR) 2 and TLR4 expression in monocytes from patients with type 1 diabetes: further evidence of a proinflammatory state. J Clin Endocrinol Metab. 2008; 93(2):578-583. [PubMed: 18029454]

53. Dasu MR, Devaraj S, Jialal I. High glucose induces IL-1 $\beta$ expression in human monocytes: mechanistic insights. Am J Physiol Endocrinol Metab. 2007; 293:E337-E346. [PubMed: 17426109]

54. Dasu MR, Devaraj S, Du Clos TW, Jialal I. The biological effects of CRP are not attributable to endotoxin contamination: evidence from TLR4 knockdown human aortic endothelial cells. J Lipid Res. 2007; 48:509-512. [PubMed: 17158793]

55. Dandona P, Thusu K, Cook S, Snyder B, Makowski J, Armstrong D, Nicotera T. Oxidative damage to DNA in diabetes mellitus. Lancet. 1996; 347(8999):444-445. [PubMed: 8618487]

56. Mohanty P, Hamouda W, Garg R, Aljada A, Ghanim H, Dandona P. Glucose challenge stimulates reactive oxygen species (ROS) generation by leucocytes. J Clin Endocrinol Metab. 2000; 85(8): 2970-2973. [PubMed: 10946914]

57. Nemoto S, Fergusson MM, Finkel T. Nutrient availability regulates SIRT1 through a forkheaddependent pathway. Science. 2004; 306:2105-2108. [PubMed: 15604409]

58. Chaudhary N, Pfluger PT. Metabolic benefits from Sirt1 and Sirt1 activators. Curr Opin Clin Nutr Metab Care. 2009; 12(4):431-437. [PubMed: 19474719]

59. Guarente L. sirtuins as potential targets for metabolic syndrome. Nature. 2006; 444:868-874. [PubMed: 17167475]

60. Jiang WJ. Sirtuins: novel targets for metabolic disease in drug development. Biochem Biophys Res Commun. 2008; 373:341-344. [PubMed: 18577374]

61. Van Der Heide LP, Hoekman MF, Smidt MP. The ins and outs of FoxO shuttling: Mechanisms of FoxO transcription and transctiptional regulations. Biochem J. 380:297-309. [PubMed: 15005655] 
62. van der Horst A, Burgering BM. Stressing the role of FOXO proteins in lifespan and disease. Nat Rev Mol Cell Biol. 8:440. [PubMed: 17522590]

63. Barthel A. FoxO proteins in insulin action and metabolism. Trends Endocrinol Metab. 2005; 16:183-189. [PubMed: 15860415]

64. Park CE, Kim MJ, Lee JH, Min BI, Bae H, Choe W, Kim SS, Ha J. Resveratrol stimulates glucose transport in C2C12 myotubes by activating AMP-activated protein kinase. Exp Mol Med. 2007; 39(2):222-229. [PubMed: 17464184]

65. Pearson KJ, Baur JA, Lewis KN, Peshkin L, Price NL, Labinskyy N, Swindell WR, Kamara D, Minor RK, Perez E, Jamieson HA, Zhang Y, Dunn SR, Sharma K, Pleshko N, Woollett LA, Csiszar A, Ikeno Y, Le Couteur D, Elliott PJ, Becker KG, Navas P, Ingram DK, Wolf NS, Ungvari Z, Sinclair DA, de Cabo R. Resveratrol delays age-related deterioration and mimics transcriptional aspects of dietary restriction without extending life span. Cell Metab. 2008; 8:157-168. [PubMed: 18599363]

66. Knutson MD, Leeuwenburgh C. Resveratrol and novel potent activators of SIRT1: effects on aging and age-related diseases. Nutr Rev. 2008; 66(10):591-596. [PubMed: 18826454]

67. Hou X, Xu S, Maitland-Toolan KA, Sato K, Jiang B, Ido Y, Lan F, Walsh K, Wierzbicki M, Verbeuren TJ, Cohen RA, Zang M. SIRT1 regulates hepatocyte lipid metabolism through activating AMP-activated protein kinase. J Biol Chem. 2008; 283(29):20015-20026. [PubMed: 18482975]

68. Chow SE, Hshu YC, Wang JS, Chen JK. Resveratrol attenuates oxLDL-stimulated NADPH oxidase activity and protects endothelial cells from oxidative functional damages. J Appl Physiol. 2007; 102(4):1520-1527. [PubMed: 17194732]

69. Park DW, Baek K, Kim JR, Lee JJ, Ryu SH, Chin BR, Baek SH. Resveratrol inhibits foam cell formation via NADPH oxidase 1-mediated reactive oxygen species and monocyte chemotactic protein. Exp Mol Med. 2009; 41(3):171-179. [PubMed: 19293636]

70. Ungvari Z, Labinskyy N, Mukhopadhyay P, Pinto JT, Bagi Z, Ballabh P, Zhang C, Pacher P, Csiszar A. Resveratrol attenuates mitochondrial oxidative stress in coronary arterial endothelial cells. Am J Physiol Heart Circ Physiol. 2009; 297(5):H1876-H1881. [PubMed: 19749157]

71. Orimo M, Minamino T, Miyauchi H, Tateno K, Okada S, Moriya J, Komuro I. Protective Role of SIRT1 in Diabetic Vascular Dysfunction. Arterioscler Thromb Vasc Biol. 2009; 29(6):889-894. [PubMed: 19286634]

72. de Kreutzenberg SV, Ceolotto G, Papparella I, Bortoluzzi A, Semplicini A, Dalla Man C, Cobelli C, Fadini GP, Avogaro A. Downregulation of the longevity-associated protein sirtuin 1 in insulin resistance and metabolic syndrome: potential biochemical mechanisms. Diabetes. 2010; 59(4): 1006-1015. [PubMed: 20068143]

73. Ghanim H, Sia CL, Abuaysheh S, Korzeniewski K, Patnaik P, Marumganti A, Chaudhuri A, Dandona P. An antiinflammatory and reactive oxygen species suppressive effects of an extract of Polygonum cuspidatum containing resveratrol. J Clin Endocrinol Metab. 2010; 95(9):E1-E8. [PubMed: 20534755] 

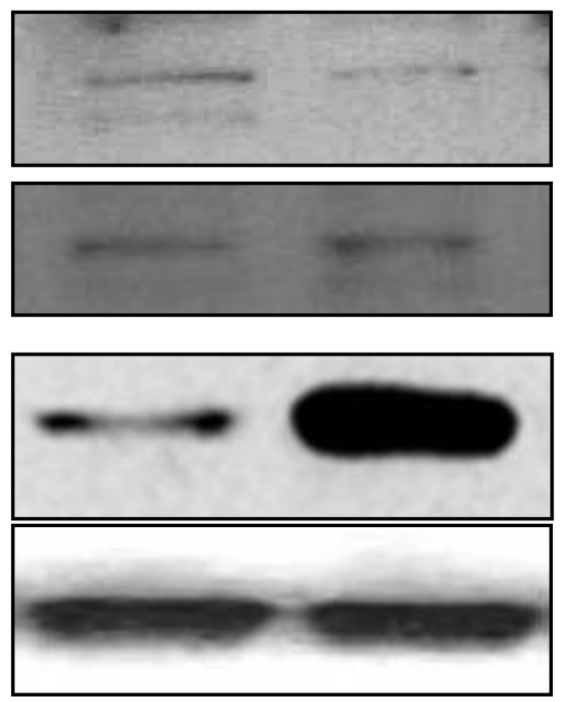

Control T1DM

\section{SIRT1}

\section{TBP (Loading control)}

\author{
p47phox
}

$\beta$ - actin

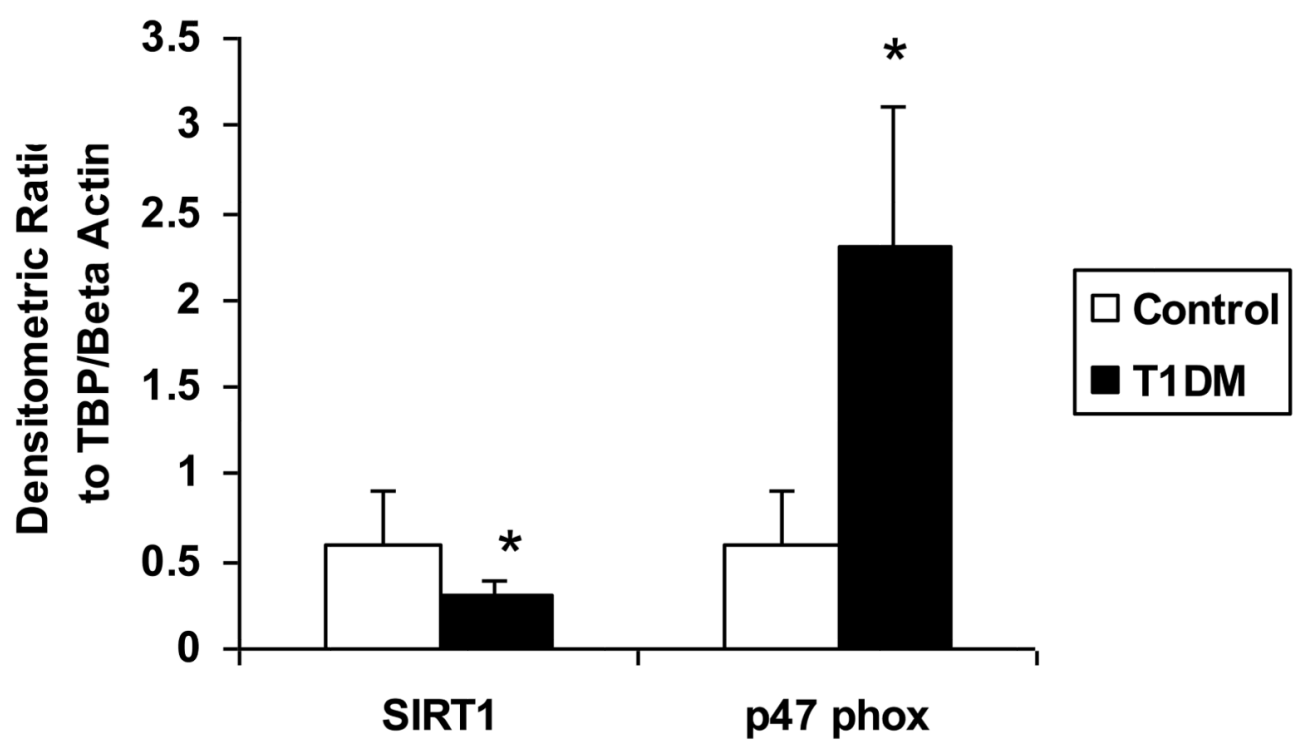

Figure 1. Decreased SIRT1 expression and increased p47phox expression in T1DM subjects compared to normal subjects

Monocytes were isolated from fasting blood obtained from T1DM and normal subjects as described in Methods. For the western blot analysis, protein was subjected to SDS-PAGE and used SIRT1 and p47phox antibodies (1:1000 dilutions) as detailed in Materials and Methods Section. Equal loading of protein was confirmed by stripping the immunoblot and reprobing it for TATA binding protein (TBP) and $\beta$-actin. The immunoblot shown here are representative of 8 experiments with similar results. Densitometric ratios to TBP and Beta actin are provided in the lower panel. $*$ p $<0.01$ compared to controls 
A
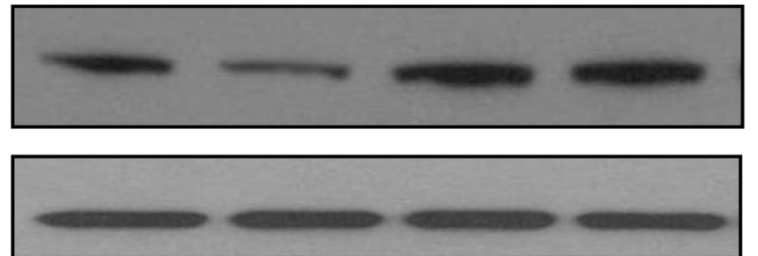

NG HG
$3 \quad 6 \mu M$

\section{HG}

\section{SIRT1}

\section{TBP (Loading control)}

\section{Resveratrol}

B HDAC activity

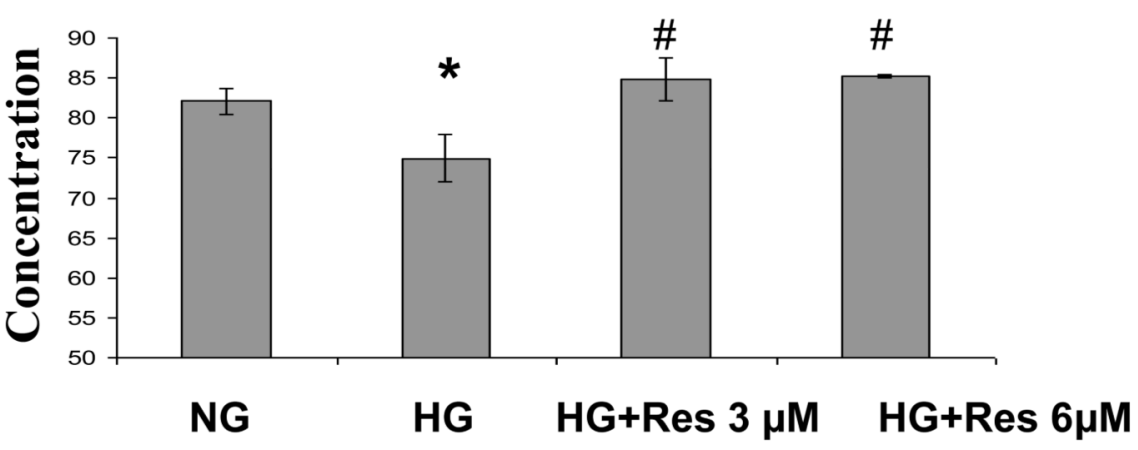

$\mathbf{C}$

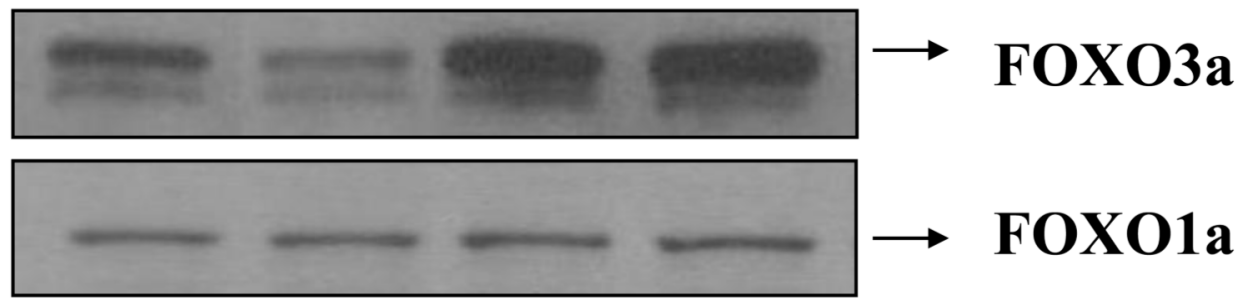

\section{TBP (loading control)}

\section{$\begin{array}{lllll}\text { NG } & \text { HG } & 3 & 6 \mu M & \text { Resveratrol }\end{array}$ \\ HG}

Figure 2. A) Resveratrol treatment significantly induced SIRT1 gene expression and HDAC activity in HG-induced THP-1 cells in vitro (B) Induced HDACs activity by resveratrol treatment in HG-induced THP-1 cells. (C) Resveratrol treatment induces FOXO3a gene expression in HG-induced THP-1 cells

(A and C) For the western blot analysis, protein was subjected to SDS-PAGE and used SIRT1, FOXO3a and FOXO1a antibodies (1:1000 dilutions) as detailed in Materials and Methods Section. Equal loading of protein was confirmed by stripping the immunoblot and reprobing it for TATA binding protein (TBP). The immunoblot shown here are representative of three independent experiments with similar results. (B) Following treatment of cells with 3 and $6 \mu \mathrm{mol} / \mathrm{L}$ of reveratrol for $48 \mathrm{~h}$ as described in Methods, cells 
were harvested and nuclear lysates were prepared. $10 \mu \mathrm{g}$ of nuclear lysate protein from each group were taken for determination of HDACs activity. The experiment was done according to the manufacturer's instructions. Absorbance was taken at $405 \mathrm{~nm}$ and $440 \mathrm{~nm}$ by using ELISA reader. Results were shown as mean \pm SD of 5 different experiments. *a: $\mathrm{p}<0.05$ compared to NG; *p<0.05; **p<0.01 compared to HG 
A
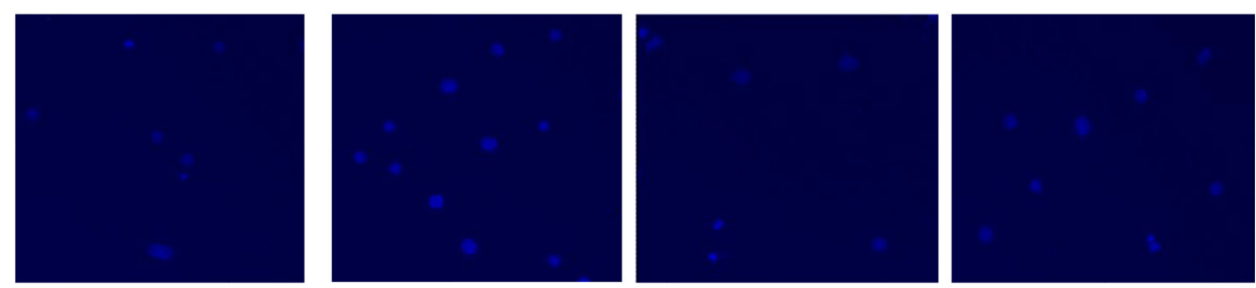

DAPI
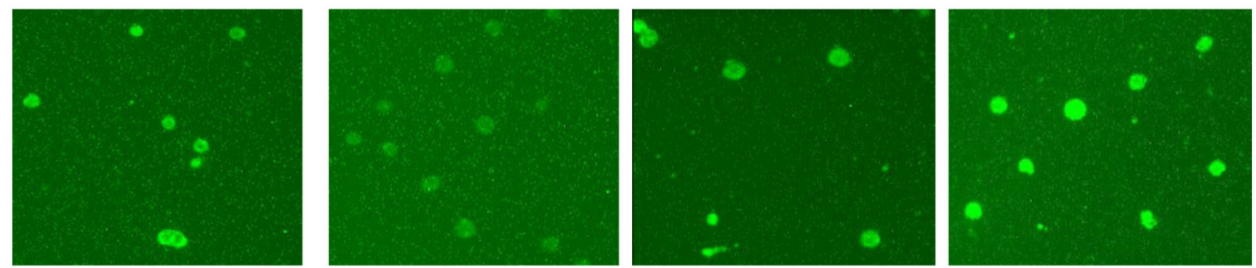

FOXO3a

B
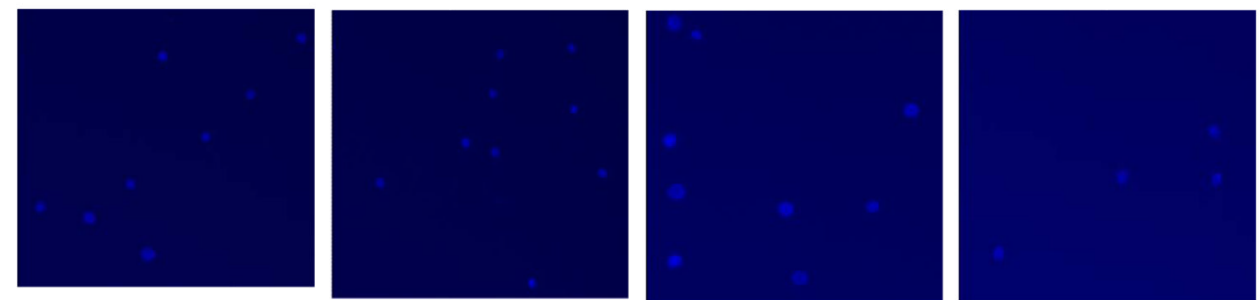

DAPI

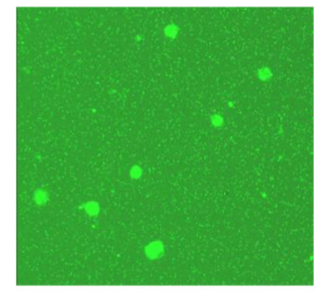

NG

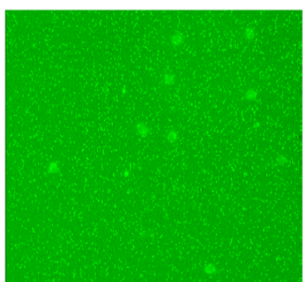

HG
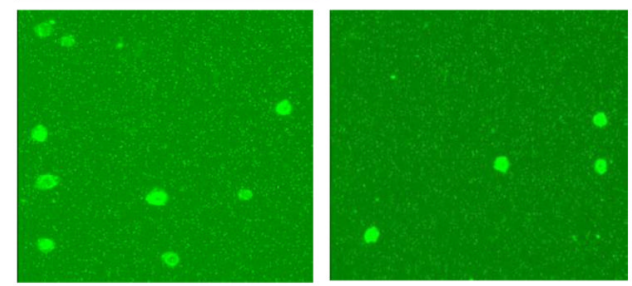

\section{HG +3 $\mu \mathrm{M}$}

\section{HG $+6 \mu \mathrm{M}$ resveratrol}

Figure 3. Resveratrol treatment induced FOXO3a in HG-induced monocytes by immunofluorescence

The cells (50-60\% confluent) were treated with 3-6 $\mu \mathrm{mol} / \mathrm{L}$ resveratrol for $48 \mathrm{~h}$. Cells were fixed with $4 \%$ formaldehyde for $30 \mathrm{~min}$ at $4^{\circ} \mathrm{C}$ and stained overnight at $4^{\circ} \mathrm{C}$ with SIRT1 and FOXO3a as described in Methods. Data from a typical experiment of 5 are shown;

Magnification $\times 400$. 
A

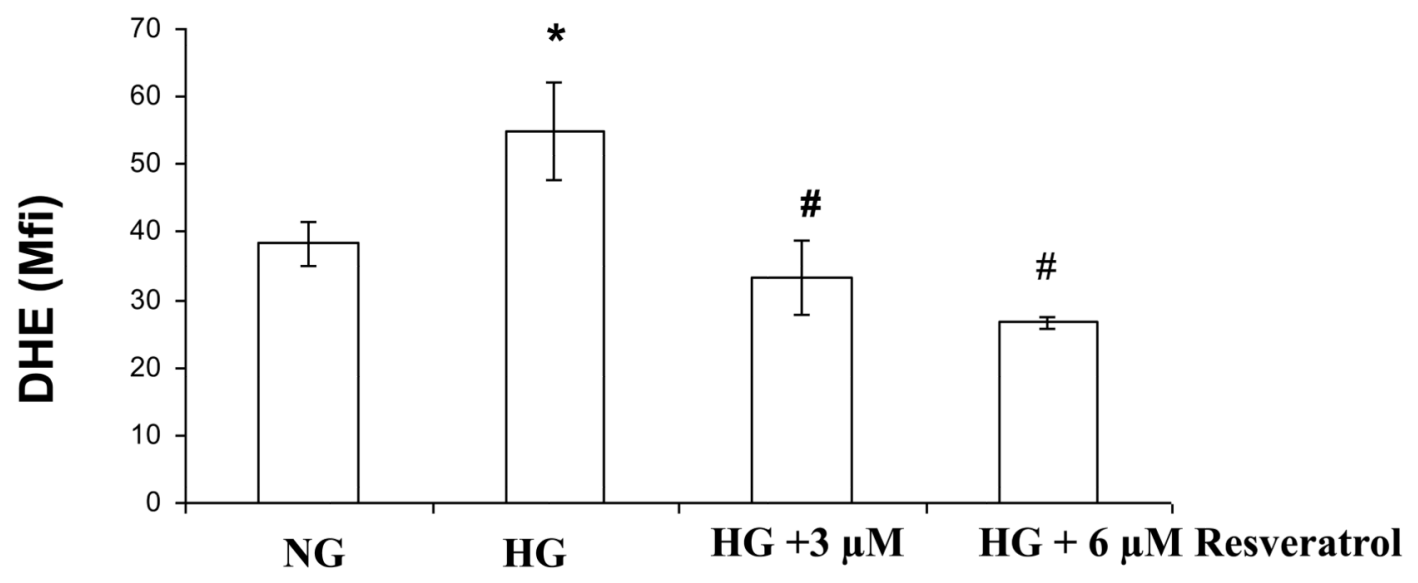

B

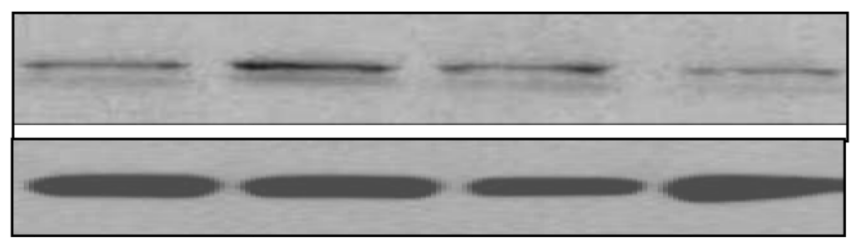

p47phox (Membrane)

NG HG $3 \quad 6 \mu M \quad$ Resveratrol

HG

Figure 4. Effect of resverarol on superoxide production and p47phox gene expression level in HG -induced THP-1 cells

(A) NG, HG and HG-resveratrol treated cells were incubated with $5 \mu \mathrm{mol} / \mathrm{L}$ dihydroethidium $(\mathrm{DHE})$. Cells $\left(1 \times 10^{5}\right)$ were stained with $5 \mu \mathrm{mol} / \mathrm{L}$ dihydroyethidium for 30 minutes at $37^{\circ} \mathrm{C}$ and were washed and resuspended in PBS. The oxidative conversion of dehydroxyethidium to ethidium was measured by flow cytometry. (B) For the western blot analysis, protein was subjected to SDS-PAGE and used p47phox antibody (1:1000 dilution) as detailed in Materials and Methods Section. Equal loading of protein was confirmed by stripping the immunoblot and reprobing it for $\beta$-actin. The immunoblot shown here are representative of three independent experiments with similar results. 
A

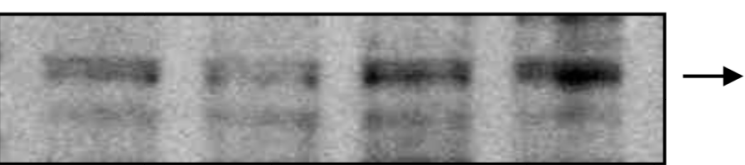

$\rightarrow \quad$ FOXO3a
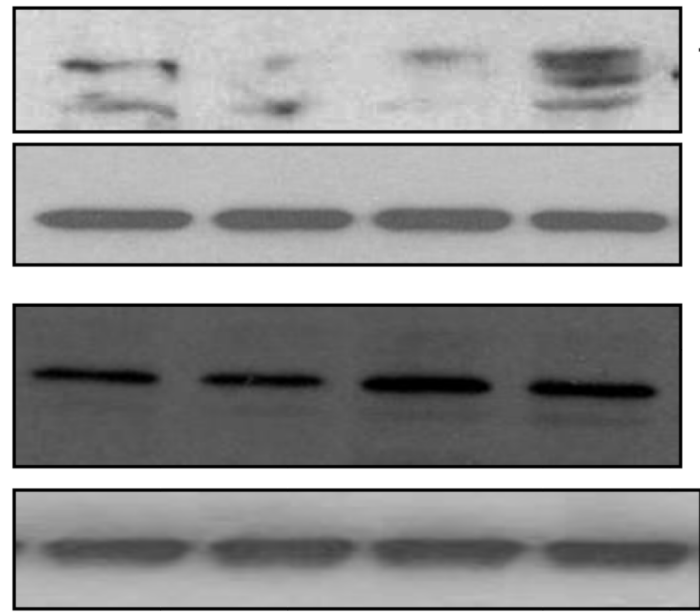

$3 \quad 6 \mu M$

\section{$\longrightarrow$ SIRT1}

\section{TBP (loading control)}

\section{P47phox (membrane)}

\author{
$\beta$ - actin
}

$\begin{array}{lrrrr}\text { NG } & \text { HG } & 3 & 6 \mu M & \text { Resveratrol } \\ \text { +SIRT1sIRNA } & \text { HG+SIRT1siRNA }\end{array}$

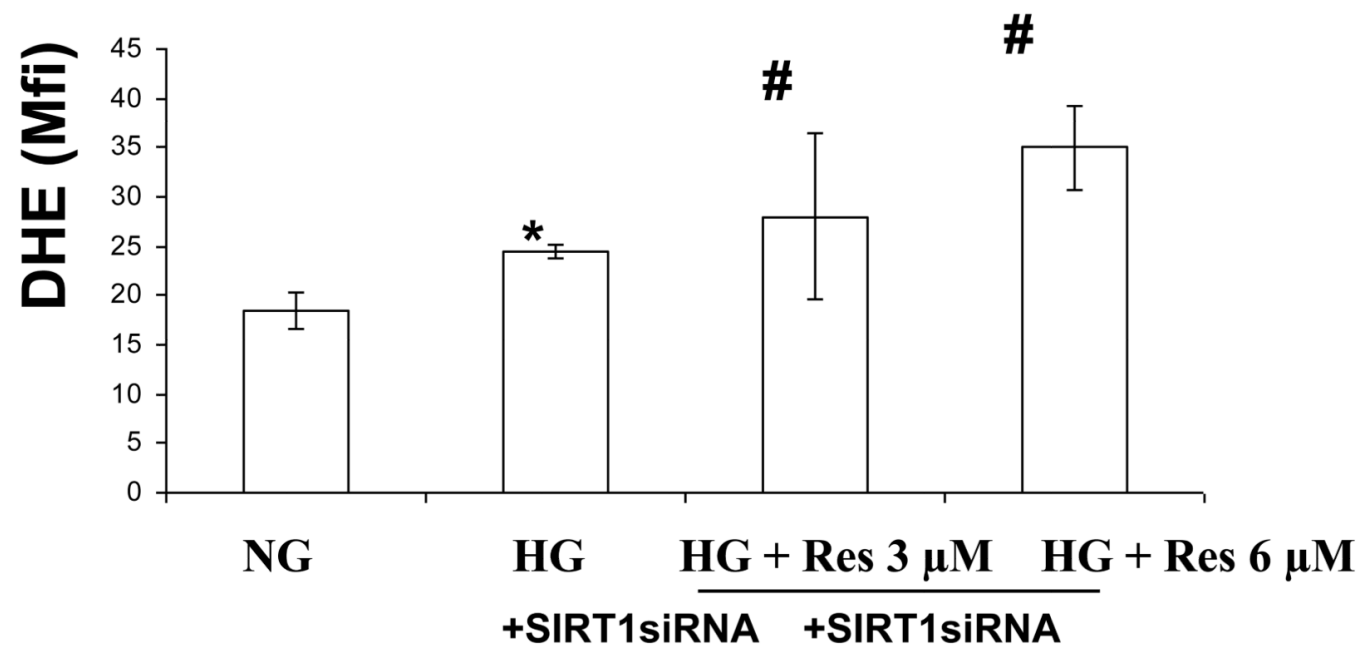

Figure 5. Modulation of Foxo3a and p47hox using SiRNA-SIRT1 transfection under highglucose conditions

Cell were transfected using lipofectamine with prevalidated siRNA-SIRT1. Subsequently, human monocytic cells $\left(1 \times 10^{5}\right.$ cells/ml $)$ were cultured in presence of NG and HG conditions in absence or presence of resverarol $(3-12 \mu \mathrm{mol} / \mathrm{L})$ for $48 \mathrm{~h}$. Then, cells were washed with phosphate-buffered saline (PBS) and then harvested. (A) NG, HG and HGresveratrol treated cells (transfected with siRNA to SIRT1) were incubated with $5 \mu \mathrm{mol} / \mathrm{L}$ dihydroethidium (DHE). Cells $\left(1 \times 10^{5}\right)$ were stained with $5 \mu \mathrm{mol} / \mathrm{L}$ dihydroyethidium for 30 minutes at $37^{\circ} \mathrm{C}$ and were washed and resuspended in PBS. The oxidative conversion of dehydroxyethidium to ethidium was measured by flow cytometry. (B) For the western blot 
analysis, protein was subjected to SDS-PAGE and used p47phox antibody (1:1000 dilution) as detailed in Materials and Methods Section. Equal loading of protein was confirmed by stripping the immunoblot and reprobing it for $\beta$-actin. The immunoblot shown here are representative of three independent experiments with similar results. 


\section{High glucose}
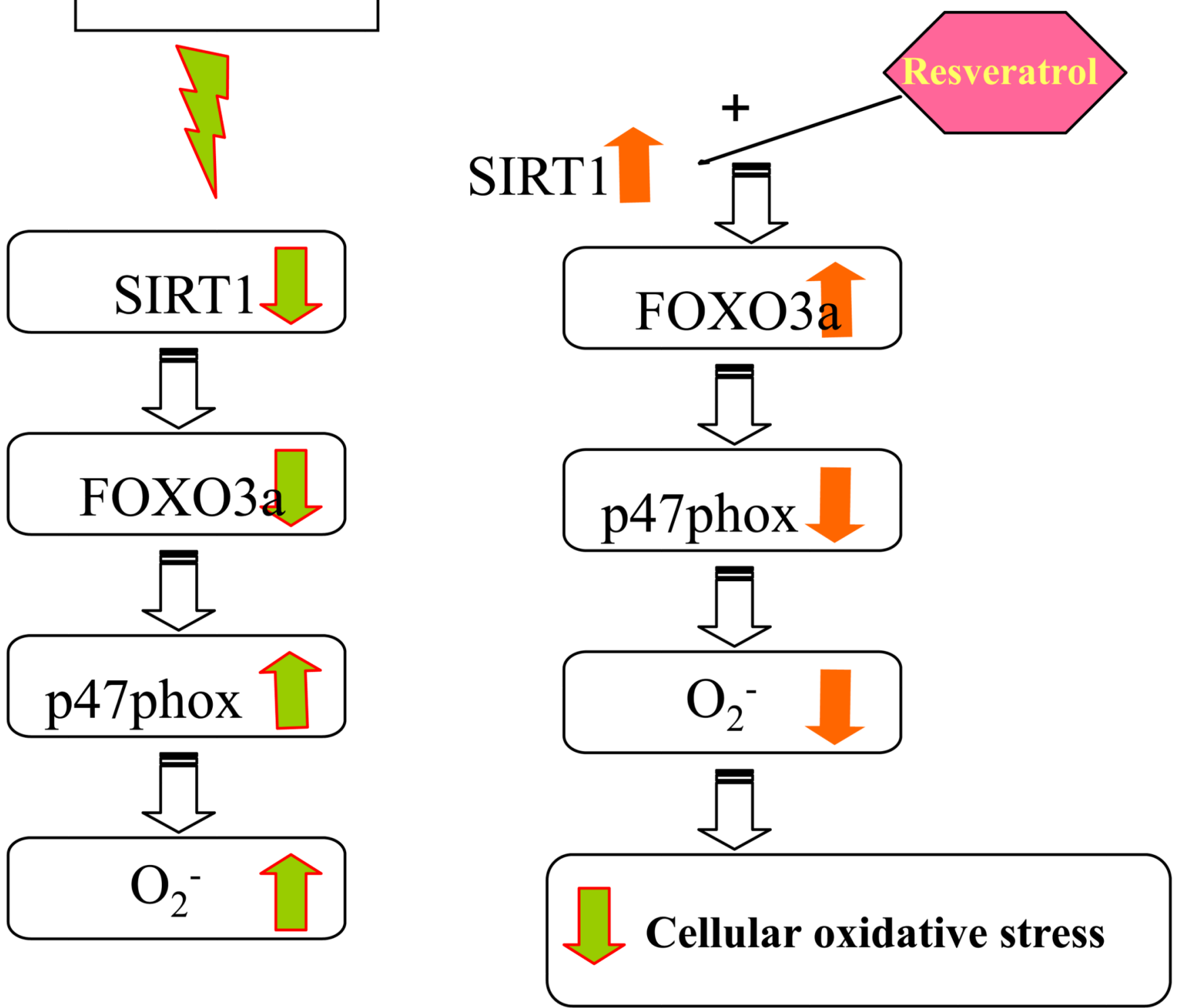

Figure 6.

Proposed mechanisms by which resveratrol regulates SIRT1-FOXO3a leading to decreased p47phox expression and ROS production. High glucose suppresses SIRT1-FOXO3a pathway leading to increaesed $\mathrm{p} 47$ phox gene expression and ROS production. Resveratrol treatment of HG-induced cells activates the HDACs activity and induces SIRT1 and FOXO3a expression, subsequently suppressing production of ROS and p47phox activation. 